\title{
INTRODUKSI TEKNOLOGI DALAM MENUNJANG USAHA TERNAK ITIK DI DESA PASLATEN KECAMATAN KAKAS KABUPATEN MINAHASA
}

\author{
Meiske L. Rundengan, F. H. Elly*, I. D.R. Lumenta, L. S. Kalangi, \\ T. F.D. Lumy dan Z. Poli
}

\author{
Fakultas Peternakan Universitas Sam Ratulangi Manado, 95115
}

\begin{abstract}
ABSTRAK
Tujuan pemeliharaan ternak itik yang dilakukan anggota kelompok Kinakas Jaya adalah untuk produksi telur dan daging. Ternak itik menghasilkan telur hanya sekitar 60-70 persen dari jumlah pemilikan ternak itik oleh anggota kelompok. Rendahnya produksi dan produktivitas ternak itik menyebabkan pendapatan yang diterima anggota kelompok rendah dan tidak kontinyu. Padahal permintaan terhadap produk ternak itik mengalami peningkatan dari tahun ke tahun. Usaha ternak itik di Sulawesi Utara memiliki prospek pengembangan sangat besar ditinjau dari jumlah penduduk yang cenderung meningkat setiap tahunnya. Masalahnya pemeliharaan ternak itik oleh anggota kelompok masih bersifat tradisional dan ketersediaan DOD tidak kontinyu. Berdasarkan permasalahan tersebut, telah dilakukan pemberdayaan terhadap anggota kelompok melalui penyuluhan dan introduksi mesin tetas. Penelitian ini bertujuan untuk mengetahui sejauhmana kegiatan pemberdayaan dalam menunjang usaha ternak itik di desa Paslaten Kecamatan Kakas. Metode penelitian yang digunakan adalah metode survei. Lokasi sampel adalah Desa Paslaten yang ditentukan secara purposive sampling yaitu desa yang memiliki kelompok tani
\end{abstract}

*Korespondensi (corresponding uthor) Email : meiske.rundengan@yahoo.com ternak itik. Responden adalah anggota kelompok Kinakas Jaya yaitu anggota kelompok yang mengembangkan ternak itik dan telah diberdayakan melalui introduksi teknologi. Hasil penelitian menunjukkan bahwa umur responden berkisar antara 42-50 tahun dengan tingkat pendidikan SMP $(37.5 \%)$ dan SMA $62.5 \%$. Penyuluhan telah dilakukan dan direspon baik oleh anggota kelompok. Selanjutnya, introduksi mesin tetas telah dilakukan dan petani peternak telah melakukan proses penetasan telur. Berdasarkan hasil penelitian dapat disimpulkan bahwa adopsi teknologi oleh anggota kelompok telah berhasil tetapi tingkat keberhasilan penetasan telur masih rendah. Saran yang disampaikan perlu peningkatan frekuensi penyuluhan dan penerapan teknologi.

Kata Kunci : Introduksi, Teknologi, itik

\section{ABSTRACT}

INTRODUCTION OF TECHNOLOGY IN SUPPORT FARMING OF DUCK IN PASLATEN VILLAGE DISTRICT OF KAKAS REGENCY OF MINAHASA. The purpose of raising ducks by members of the Kinakas Jaya group was to produce eggs and meat. The eggs produced were around 60-70 percent of the total number of duck members owned by group members. The low production and 
productivity of ducks causes low income received by group members and not continuous whereas the demand for duck products has increased from year to year. Duck farming in North Sulawesi has a very large development prospect in terms of the population that tends to increase every year. The problem with raising ducks by group members was still traditional and the availability of DOD was not continuous. Based on these problems, empowerment of group members was carried out, namely extension and introduction of hatching machines. The research was conducted with the aim to find out the extent of empowerment activities in supporting duck business in Paslaten Village, Kakas District. The research method used was a survey method. The sample location was Paslaten Village, which was determined by purposive sampling (a village with a group of duck farmers). Respondents were members of the Kinakas Jaya group who were empowered through the introduction of technology. The age of the respondents ranged from 42-50 years with junior high school level (37.5\%) and high school $62.5 \%$. Extension was done and responded well by group members. Furthermore, the process of hatching eggs was carried out by group members. Based on the results of the study it can be concluded that the technology was successfully adopted by group members, but the success rate of hatching eggs was still low. Suggestions submitted need to increase the frequency of counseling and application of technology

Keywords: introduction, technology, Ducks

\section{PENDAHULUAN}

Ternak itik adalah salah satu ternak

yang dikembangkan petani di Desa Paslaten di Kecamatan Kakas sebagai sumber pendapatan. Prasetyo et al. (2010) bahwa usaha peternakan itik semakin diminati sebagai alternatif sumber pendapatan bagi masyarakat di pedesaan maupun di sekitar perkotaan. Usaha ternak itik ini sudah lama dikembangkan oleh petani dan sudah turun temurun. Pengembangan ternak itik di wilayah ini dilakukan baik secara perorangan maupun secara berkelompok. Salah satu kelompok ternak itik di Desa Paslaten adalah kelompok Kinakas Maju yang telah didirikan sejak tahun 2013. Tetapi usaha ternak itik masih diusahakan secara sambilan dengan system pemeliharaan pada umumnya bersifat tradisional. Budi et al. (2015) dan Thermolen et al. (2016) menyatakan bahwa kondisi ini terjadi di wilayah mana saja di Indonesia. Sistem tradisional ini ditunjukkan dari pemeliharaan ternak itik dengan cara dilepas atau diumbar disiang hari atau digembalakan ke areal persawahan. Ternak itik mengkonsumsi sisa-sisa padi yang rontok saat panen dan hewan-hewan kecil yang hidup di lahan sawah. Sistem ini oleh Elly (2011) disebut sebagai sistem pemeliharaan ekstensif. Dalam hal ini ternak itik tidak dikandangkan dan berdampak terhadap rendahnya produksi dan produktivitas ternak itik. Rendahnya 
produksi dan produktivitas disebabkan kurangnya pakan yang dikonsumsi oleh ternak itik. Harga pakan tidak tersedia secara kontinyu dan harganya mahal sehingga sulit dijangkau oleh petani.

Tujuan pemeliharaan ternak itik yang dilakukan anggota kelompok Kinakas Jaya adalah untuk telur sekaligus untuk daging. Ternak itik menghasilkan telur hanya sekitar 60-70 persen dari jumlah pemilikan ternak itik oleh anggota kelompok. Pemilikan ternak itik hanya bekisar antara 50 sampai 200 ekor. Hal ini disebabkan karena ketersediaan bibit masih kurang. Petani peternak sebagai anggota kelompok mendapatkan bibit melalui toko makanan ternak ataupun melalui petani yang melakukan penetasan telur. Rendahnya produksi dan produktivitas ternak itik menyebabkan pendapatan yang diterima anggota kelompok rendah dan tidak kontinyu. Padahal permintaan terhadap produk ternak itik mengalami peningkatan dari tahun ke tahun. Usaha ternak itik di Sulawesi Utara memiliki prospek pengembangan sangat besar ditinjau dari jumlah penduduk yang cenderung meningkat setiap tahunnya. Permasalahannya pemeliharaan ternak itik oleh anggota kelompok masih bersifat tradisional dan ketersediaan bibit DOD tidak kontinyu. Berdasarkan permasalahan tersebut maka telah dilakukan pemberdayaan terhadap anggota kelompok melalui penyuuhan dan introduksi mesin tetas. Penelitian ini bertujuan untuk mengetahui sejauhmana kegiatan pemberdayaan dalam menunjang usaha ternak itik di desa Paslaten Kecamatan Kakas.

\section{MATERI DAN METODE PENELITIAN}

Materi penelitian ini adalah ternak itik (jumlah yang dimiliki anggota kelompok), pakan dan teknologi yang diintroduksi yaitu mesin tetas dan telur tetas. Introduksi mesin tetas untuk mengatasi sulitnya memperoleh bibit (DOD), telur tetas diintroduksi untuk melatih anggota kelompok menggunakan mesin tetas. Pemberdayaan dilakukan untuk melatih petani mengelola usaha ternak itik yang baik dan benar. Metode penelitian yang digunakan adalah metode survei. Lokasi sampel adalah Desa Paslaten yang ditentukan secara purposive sampling yaitu desa yang memiliki kelompok tani ternak itik. Responden adalah anggota kelompok Kinakas Jaya (8 orang) yaitu anggota kelompok yang mengembangkan ternak itik dan telah diberdayakan melalui 
introduksi teknologi. Analisis data secara deskriptif.

\section{HASIL DAN PEMBAHASAN}

Hasil penelitian menunjukkan bahwa penerimaan anggota kelompok dianggap rendah yang disebabkan mahalnya harga pakan. Anggota kelompok sering menghadapi kendala tersebut sehingga berdampak terhadap kontinuitas usaha mereka. Kebutuhan pakan yang dikonsumsi oleh itik dewasa sebanyak 170227 gram, bahkan konsumsi pakan oleh itik betina dewasa yang sedang bertelur penuh sebanyak 283 gram setiap harinya (Supriyadi, 2009). Dampaknya proses produksi ternak itik yang dilakukan anggota kelompok adalah dengan cara ternak itik digembalakan di lahan sawah sesudah panen. Padahal, pengembangan ternak itik yang dilakukan sesuai dengan yang dianjurkan berdampak terhadap peningkatan produktivitas ternak itik sehingga dapat menjamin peningkatan kesejahteraan anggota kelompok. Berdasarkan beberapa hasil penelitian, kontribusi usaha ternak itik terhadap pendapatan keluarga sebesar 35,9 \% (Fauzi, 2011). Selanjutnya menurut Marmiati (2011), pemilikan ternak itik sebanyak 150 ekor dapat memberikan keuntungan sebesar Rp 682.038,46/bulan.
Nilai rentabilitas usaha ternak itik petelur sesuai hasil penelitian Endoh et al. (2016) adalah sebesar $\mathrm{R}=69 \%$, artinya keuntungan masih dapat ditingkatkan dengan modal yang digunakan petani.

Hasil penelitian menunjukkan bahwa bibit itik (DOD) sulit diperoleh anggota kelompok sehingga menyebabkan pengembangan usaha oleh anggota kelompok menjadi lambat dan sering tidak kontinyu. Bibit itik (DOD) dibeli oleh anggota kelompok dengan harga berkisar Rp 12.500 sampai Rp 15.000/ekor. Harga itik betina siap bertelur cukup mahal yaitu Rp 75.000/ekor, tetapi petani tetap membelinya untuk memaksimumkan utilitas mereka. Anggota kelompok dalam hal ini berupaya untuk memenuhi kecenderungan permintaan produk ternak itik yang semakin meningkat (Budi et al. 2015). Kontribusi itik penghasil daging pada produksi daging nasional masih rendah yaitu sebanyak tiga persen, hal ini disebabkan dominasi kontribusi daging itik di Indonesia adalah berasal dari peternakan rakyat (Thermolen et al. 2016). Menurut Rukmiasih et al. (2015) bahwa sebenarnya petani peternak itik sudah banyak memanfaatkan ternak itik sebagai penghasil daging dan memberikan keuntungan bagi mereka. Hasil penelitian 
di Minahasa oleh Lembong et al. (2015) menunjukkan bahwa pemeliharaan ternak itik yang dikandangkan mencapai break even point pada pemilikan 51 ekor per periode dengan bobot badan rata-rata 2,5 kg/ekor.

Hasil penelitian menunjukkan bahwa usaha ternak itik dikelola anggota kelompok dengan cara tradisional sebagai usaha sambilan. Usaha ternak itik yang tradisional memiliki ciri-ciri sebagai berikut: rendahnya penerapan teknologi, skala usaha rumahtangga, ternak itik tidak dikandangkan (Risqina, 2011 dan Taufik et al. 2013 menyatakan bahwa produksi telur semakin tinggi apabila ternak itik dikandangkan), dan belum memperhatikan kesehatan ternak itik. Kondisi ini ditunjang juga dengan rendahnya pengetahuan anggota kelompok berkaitan dengan usaha yang bersifat intensif dan komersial. Usaha yang belum secara intensif dan komersial di Indonesia (termasuk di wilayah penelitian) sesuai dengan beberapa peneliti seperti Budi et al (2015) dan Thermolen et al (2016).

Pemberdayaan anggota kelompok sangat dibutuhkan dalam meningkatkan pengetahuan mereka. Metode pendekatan yang digunakan adalah metode aplikasi teknologi tepat guna dengan teknik pembelajaran orang dewasa (andragogik). Metode ini lebih memudahkan tercipta mekanisme, prosedur, iklim dan suasana yang mendukung terjadinya proses pembelajaran secara mandiri serta partisipatif dari kelompok sasaran. Selanjutnya, pemahaman atas nilai dan norma sangat kuat melekat pada kelompok sasaran. Hal ini menyebabkan kelompok sasaran dalam memahami suatu informasi tidak serta merta diterima melainkan dibandingkan dengan nilai dan norma yang sudah melekat dalam diri mereka yang terbentuk berdasarkan pengalaman mereka. Penyuluhan dan introduksi teknologi telah dilakukan terhadap anggota kelompok sehingga mereka dapat memperbaiki cara pemeliharaan ternak itik sesuai yang disarankan. Penyuluhan bertujuan mengubah perilaku sumberdaya anggota kelompok ke arah yang lebih baik. Beberapa falsafah penyuluhan adalah: (1) penyuluhan menyandarkan programnya pada kebutuhan petani; (2) penyuluhan pada dasarnya adalah proses pendidikan untuk orang dewasa yang bersifat non formal. Tujuannya untuk mengajar petani, meningkatkan kehidupannya dengan usahanya sendiri, serta mengajar petani untuk menggunakan sumberdaya alamnya dengan bijaksana; dan (3) penyuluh 
bekerja sama dengan organisasi lainnya untuk mengembangkan individu, kelompok dan bangsa. Pelaksanaan penyuluhan dengan menyiapkan brosur-brosur.

Proses produksi ternak itik yang bersifat intensif dan komersial tergantung pada karakteristik anggota kelompok sebagai responden. Karakteristik dimaksud diantaranya tingkat umur dan pendidikan responden. Umur responden dinyatakan sebagai umur produktif karena berkisar antara 42-50 tahun. Distribusi tingkat pendidikan kelompok yaitu 37.5 persen responden lulus Sekolah Menengah Tingkat Pertama, dan 62.5 persen responden lulus Sekolah Menengah Tingkat Atas. Kondisi ini menunjukkan bahwa tingkat pendidikan responden dikategorikan cukup memadai. Tetapi, keadaan pendidikan tersebut belum menjamin tingkat adopsi teknologi dari anggota kelompok. Pendidikan informal seperti penyuluhan dapat ditingkatkan sehingga adopsi teknologi dapat ditingkatkan. Penyuluhan dan pelatihan bagi kelompok petani peternak itik sangat dibutuhkan sehingga berdampak terhadap terciptanya motivasi tinggi untuk membangun peternakan secara mandiri dan berkelanjutan (Zubaidah et al. 2015).
Hasil penelitian menunjukkan bahwa penyuluhan telah dilakukan dan direspon baik oleh anggota kelompok. Hal ini ditunjang oleh Indreswari et al. (2014), bahwa penyuluhan cukup efektif dalam meningkatkan pengetahuan petani dalam hal pemahaman terhadap manajemen pemeliharaan itik. Dalam hal ini kelembagaan penyuluh juga berpengaruh terhadap perilaku petani dalam adopsi teknologi (Taufik et al. 2013). Menurut Sunaryo dan Wadjdi (2018) bahwa dengan penyuluhan berdampak terhadap keinginan petani untuk beternak itik. Selanjutnya, introduksi mesin tetas telah dilakukan dan petani peternak telah melakukan proses penetasan telur. Kondisi ini menunjukkan bahwa anggota kelompok telah merespon 100 persen kegiatan penyuluhan dan introduksi mesin tetas. Tetapi, telur itik yang menetas hanya sekitar 15 persen. Hal ini disebabkan karena faktor telur yang belum memiliki daya tetas yang tinggi dan faktor listrik. Menururt Widyaningrum et al. (2014), telur tetas yang berkualitas dapat diperoleh dari induk yang berkualitas baik, dengan perbandingan jantan dan betina (sex ratio) yang seimbang, sementara untuk mengetahui telur yang fertil atau bertunas, terlebih dahulu harus dilakukan penetasan. Implikasinya 
pengetahuan tentang pemilihan terhadap telur tetas sangat dibutuhkan anggota kelompok. Hal ini tentunya dibutuhkan peningkatan frekuensi pemberdayaan anggota kelompok.

\section{KESIMPULAN DAN SARAN}

Berdasarkan hasil penelitian dapat disimpulkan bahwa adopsi teknologi oleh anggota kelompok telah berhasil tetapi tingkat keberhasilan penetasan telur masih rendah. Saran yang disampaikan perlu peningkatan frekuensi penyuluhan dan penerapan teknologi.

\section{UCAPAN TERIMA KASIH}

Terima kasih kepada Rektor Universitas Sam Ratulangi yang telah memberikan kesempatan kepada penulis untuk memperoleh dana PNBP dengan skim PKM.

\section{DAFTAR PUSTAKA}

Budi, E.S., E. Yektiningsih dan E. Priyanto. 2015. Profitabilitas usaha ternak itik petelur di Desa Kebonsari Kecamatan Candi, Sidoarjo. Jurnal Agraris 1 (1) : 3237.

Elly, F.H. 2011. Analisis Usaha Ternak Itik. Makalah Disampaikan pada Temu Lapang Kelompok Ternak Itik di Kecamatan Langowan. Kamis, 6 Oktober 2011. Pelaksana Tim BPTP Kalasey, Sulawesi Utara.
Endoh, B.G., A. Makalew., M.A.V. Manese dan T.F.D. Lumy. 2016. Analisis rentabilitas usaha ternak itik petelur di Desa Wolaang Kecamatan Langowan Timur. Kabupaten Minahasa. Jurnal Zootek 36 (1) : 198-206.

Fauzi, Z. 2011. Analisis Ekonomi Usaha Ternak Itik dan Sumbangannya Terhadap Pendapatan Keluarga (Di Desa Petangguhan, Kecamatan Galang, Kabupaten Deli Serdang). Skripsi. Fakultas Pertanian. Universitas Sumatera Utara. Medan. Indreswari, R., A. Ratriyanto dan R. Dewanti. 2014. Evaluasi penyuluhan pemeliharaan itik lokal jantan berbasis metode inditik terhadap tingkat pengetahuan dan sikap petani di Desa Gaum, Kecamatan Tasikmadu, Kabupaten Karanganyar. Jurnal Sains Peternakan 12 (1) : 56-60.

Lembong, J.G.. N.M. Santa., A. Makalew dan F.H. Elly. 2015. Analisis break even point usaha ternak itik pedaging (studi kasus pada usaha ternak itik milik kelompok Masawang di Desa Talikuran Kecamatan Remboken). Jurnal Zootek 35 (1) : 39-45.

Marmiati. 2011. Analisis Keuntungan Usaha Ternak Itik Petelur di Kecamatan Remboken. Skripsi. Fakultas Peternakan. UNSRAT. Manado.

Prasetyo, L.H., P.P. Ketaren., A.R. Setioko., A. Suparyanto., E. Juwarini., T. Susanti dan S. Sopiyana. 2010. Panduan Budidaya dan Usaha Ternak Itik. Balai Penelitian Ternak Ciawi, Bogor.

Rukmiasih., P.R. Matitaputty., P.S. Hardjosworo dan L.H. Prasetyo. 2015. Performa pertumbuhan dan produksi karkas itik CA (itik 
cihateup x itik alabio) sebagai itik pedaging. Jurnal Peternakan Sriwijaya 4 (2) : 29-34.

Sunaryo dan F. Wadjdi. 2018. Kelompok ternak itik pedaging hasil hibridisasi kingbell Desa Gadingkulon, Dau, Kabupaten Malang. Jurnal Jipemas 1 (2) : $152-164$.

Taufik, D.K., Isbandi dan M. Dyah. 2013. Analisis pengaruh sikap peternak terhadap pendapatan pada usaha peternakan itik di Kelurahan Pesurungan Lor Kota Tegal. Jurnal Agromedia 31 (1) : 77-84.

Thermolen, B., L. Herlin dan M. Paturochman. 2016. Analisis efisiensi penggunaan beberapa faktor produksi usaha ternak itik pedaging. Jurnal Ilmu Ternak 18 (1): 18-22.

Widyaningrum, P., Lisdiana dan N. R. Utami. 2014. Pelatihan manajemen pemeliharaan itik secara intensif di Kecamatan Wedung Kabupaten Demak. Jurnal Rekayasa 12 (1) : 4856.

Zubaidah, P. Rahayu, I. Anie dan Darlis. 2015. Pengolahan ternak itik afkir sebagai pangan asuh di Desa Semau Kecamatan Bram Hitam Kabupaten Tanjung Jabung Barat. Jurnal Pengabdian pada Masyarakat 30 : 25-29. 